\title{
ВПЛИВ ГЕНОТИПУ ЗА БЕТА-КАЗЕЇНОМ НА ЯКІСНІ ПОКАЗНИКИ МОЛОКА У ХУДОБИ БУРИХ ПОРІД
}

\author{
Ладика Володимир Іванович \\ доктор сільськогосподарських наук, профресор, академік НААН України \\ Сумський національний аграрний університет \\ ORCID: 0000-0001-6748-7616 \\ E-mail:v.i.ladyka@ukr.net \\ Павленко Юлія Миколаївна \\ кандидат сільськогосподарських наук, доцент \\ Сумський національний аграрний університет \\ ORCID: 0000-0002-4128-122X \\ E-mail: jasjulia@ukr.net \\ Скляренко Юрій Іванович \\ доктор сільськогосподарських наук, ст.н.С. \\ Інститут сільського господарства Північного Сходу НААН \\ ORCID: 0000-0002-6579-2382 \\ E-mail: sklyrenko9753@ukr.net
}

Ладика Любов Миколаївна кандидат сільськогосподарських наук, доцент Сумський національний аграрний університет

ORCID: 0000-0002-0796-713X E-mail: jasjulia@ukr.net

Левченко Ірина Володимирівна кандидат сільськогосподарських наук, доцент Сумський національний аграрний університет ORCID: 0000-0002-7142-2505

E-mail: jasjulia@ukr.net

У племінних стадах худоби лебединської та української бурої молочної порід проведені дослідження, метою яких було вивчити поліморфізм гену бета-казеїну та його вплив на якісний склад молока корів. Проведене генотипування 242 голів великої рогатої худоби вищеназваних порід. Визначення поліморфізму гену бета-казеїну проводили в генетичній лабораторії Інституту фізіології ім. Богомольия. Для проведення алельної дискримінації використовувалась система TagMan@Genotyping mа набір праймерів та зондів. Встановлено, що частоти алелів A1 $(0,308-0,313)$ та A2 $(0,687-0,692)$ в локусі гену бета-казеїну у тварин різних порід відрізнялися. Вищою частотою бажаного алелю А2 відрізнялася популяція корів лебединської породи $(0,692)$, а нижчою - української бурої молочної $(0,687)$. Частота алелю А1 була найменшою у корів лебединської породи (0,308), а вищою - української бурої молочної породи (0,313). Відповідно частоти генотипів A1A1, A1A2 та A2A2 в залежності від походження різнилися. Бажаний генотип частіше зустрічався у тварин лебединської порід (51\%). Гетерозиготний генотип більшою мірою був притаманний тваринам української бурої молочної породи (45\%). Вищою частотою генотипу A1A1 характеризувалися тварини лебединської породи (13\%). За даними генетикостатистичного аналізу встановлено надлишок в бета-казеїновому локусі гомозиготних варіантів A1A1 ma A2A2. Нестачу гетерозиготного A1А2 виявлено у тварин лебединської породи. Між тваринами різних генотипів виявлена різниия за якісними характеристиками молока. У тварин різних порід вміст окремих компонентів молока змінювався не однаково залежно від генотипу за бета-казеїном, але ия різниия була статистично незначущою. За вмістом жиру та білка в молоці тварини всіх генотипів відповідали стандарту порід. Таким чином можна констатувати, що формування стад 3 генотипом A2A2 за бета-казеїном не матиме негативного достовірного впливу на продуктивні ознаки корів і таким чином забезпечить збереження високих якісних показників молока худоби стад нового типу. Невелика кількість піддослідних тварин на нашу думку стала однією з причин відсутності достовірної різниці між середніми значеннями вмісту складових молока корів різних генотипів за бета-казеїном.

Ключові слова: порода, генотип, казеїн,, селекція, генетичні маркери, вміст жиру, вміст білка

DOI: https://doi.org/10.32845/bsnau.lvst.2021.4.2

Актуальним питанням в молочному скотарстві України стало вивчення поліморфізму бета-казеїну. Це пов'язано з підвищеним інтересом до аспекту здоров'я та харчування людини. Особливо це питання набуло популярності після появи публікацій результатів закордонних досліджень щодо

впливу молока на здоров'я людини. Встановлено, що молоко яке реалізується в магазинах містить в собі варіанти бета-казеїну A1, A2, В та C $[1,2]$.

Результати досліджень вказують на те, що найпоширенішими серед алелів бета-казеїну $є$ A1 і А2. Різниця між 
ними - це різні амінокислоти в 67-й позиції пептидного ланцюга. У цьому положенні А2-молоко має амінокислоту пролін, тоді як А1-молоко - гістидин [16, 17]. Дослідженнями доведено, що при перетравленні А1- молоко призводить до вивільнення пептиду, який має назву бета-казоморфін-7 (BCM-7). Із споживанням такого молока проявляються запалення, діабет I типу, серцеві захворювання, аутизм, шлунково-кишковий дискомфорт та інші захворювання у споживача. $[3,4,10,11,14]$. За останні три роки була проведена значна кількість досліджень, які доводять, що люди які споживали молоко, що містить лише А2 бета-казеїн, мали значно менш виражені симптоми запалення шлунково-кишкового тракту, порівняно з особами, які споживають звичайне молоко $[7,8$, $12,13,15]$.

У результаті було запропоновано отримання молока A2, яке містить лише бета-казеїн типу А2. Особливого розвитку цей процес набув у Новій Зеландії, Австралії, а в останні роки у Сполучених Штатах Америки та Китаї $[5,6]$. Також актуальними питаннями сьогодення серед науковців стало вивчення впливу генотипу корів за бета-казеїном на якісні та технологічні властивості молока [1].

Створення стад для виробництва молока А2 передбачає виконання певних робіт та включає тестування корів, телиць або всього маточного поголів'я. Для прискорення цього процесу науковці пропонують застосовувати штучне запліднення телиць сексованою спермою плідників з генотипом А2А2 за бета-казеїном [9].

Враховуючи актуальність даного питання у світовому масштабі метою нашої статті $€$ вивчення впливу генотипу за бета-казеїном на якісні показники молочної продуктивності худоби.

Матеріали та методи досліджень. Дослідження проведені у племінних репродукторах з розведення худоби лебединської породи ПСП «Комишанське» Охтирського району, ПЗ «Михайлівка» Лебединського району, племінному заводі та репродукторі з розведення української бурої молочної породи ДП ДГ ІСГПС НААН Сумського району, ТДВ «Маяк» Тростянецького району Сумської області у 2020-2021 роках.

Проведене генотипування корів лебединської (n=151) та української бурої молочної породи $(n=91)$.

Визначення поліморфізму гену бета-казеїну проводили в генетичній лабораторії Інституту фрізіології ім. Богомольця НАН за допомогою молекулярно-біологічного аналізу розпізнавання алелів методом полімеразно-ланцюгової реакції (ПЛР) у реальному часі.

Зразки крові відбирали у моновети об'ємом 2,7 мл ("Sarstedt", Німеччина) з наступним заморожуванням зразків та їх зберіганням при $-20^{\circ} \mathrm{C}$. ДНК для генотипування отримували із зразків за допомогою набору для очищення геномної ДНК Monarch® New England BioLab (США) згідно з протоколом виробника. Для проведення алельної дискримінації використовувалась система TagMan@Genotyping та набір праймерів та зондів.

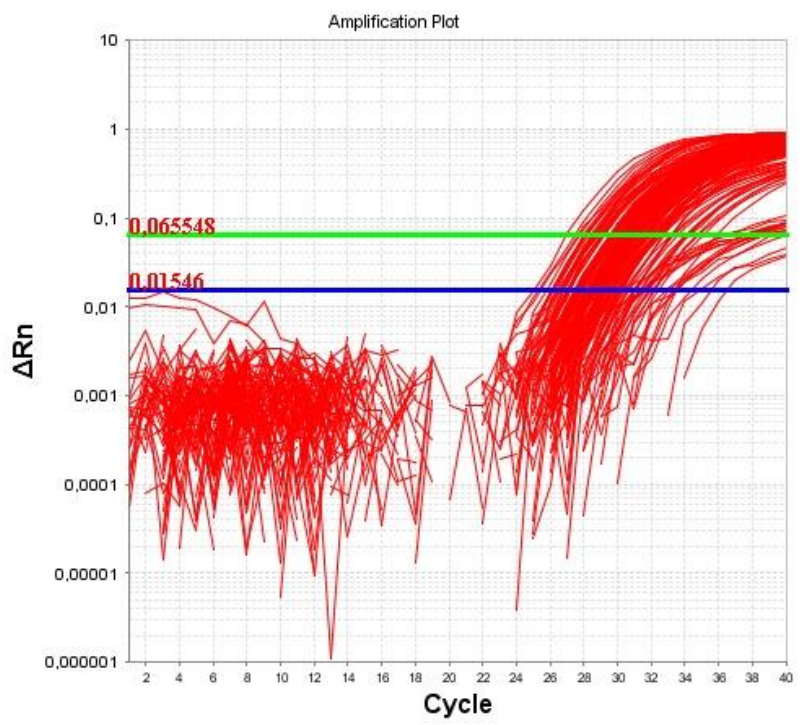

Рис 1. Ампліфікаційні криві визначення генотипу за поліморфізмом гену бета-казеїну CSN2 (rs43703011).

Підрахунок частот алелів проводили із врахуванням кількості гомозигот і гетерозигот, знайдених за відповідним алелем за формулою:

$$
P(A)=\frac{2 \mathrm{~N} 1+\mathrm{N} 2}{2 \mathrm{n}}
$$

де $\mathrm{N}_{1}$ і $\mathrm{N}_{2}$ - відповідно число гомозигот і гетерозигот для досліджуваного алеля;

$\mathrm{n}$ - число вибірки.

3 метою оцінки статистичної достовірності розбіжності розподілів одержаних результатів використовували критерій Пірсона:

$$
X^{2}=\frac{\sum(\Phi-T)^{2}}{T}
$$

де: Ф - фактична кількість генотипів; Т - теоретична кількість генотипів.

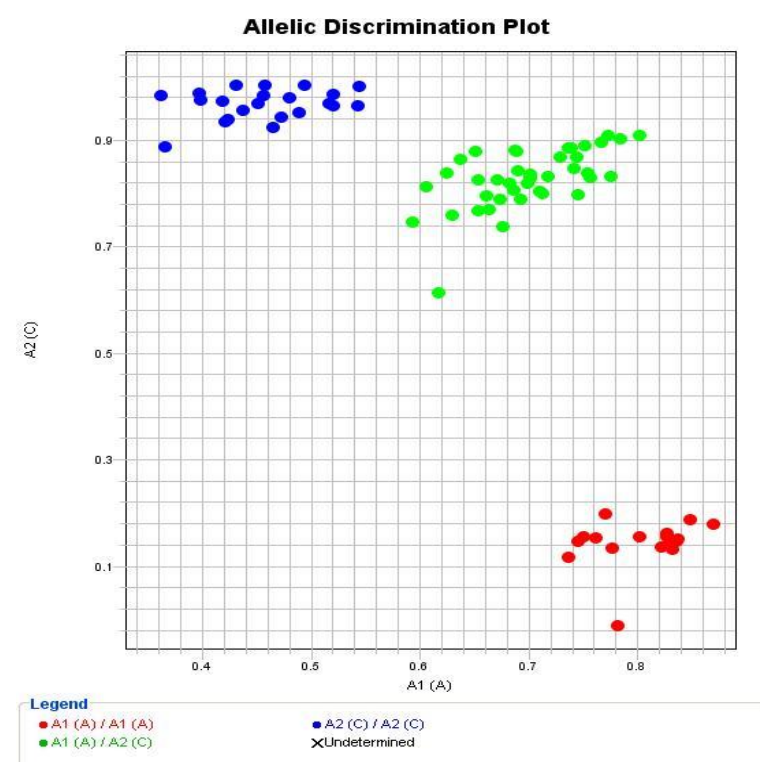

Рис 2. Алельна дискримінація за генотипами поліморфізмом гену бета-казеїну CSN2 (rs43703011).

Фактичну (наявну) гетерозиготність визначали шляхом прямого підрахунку за формулою:

$$
\mathrm{H}_{0}=\frac{\mathrm{N} 2}{\mathrm{n}}
$$


Очікувану гетерозиготність визначали за формулою:

$$
\sum_{\mathrm{E}=1-}^{n} p_{i}^{2}
$$

де $p_{1}, p_{2}, \ldots . p_{n}$ - частоти алелів.

Для генетичної характеристики поголів'я також визначали рівень гомозиготності (Ca):

рівень поліморфності, $\mathrm{Na}$

$$
C a=\left(p(A)^{2}+p(B)^{2}\right)^{*} 100 ;
$$

$$
\mathrm{Na}=1 / \mathrm{Ca}
$$

тест гетерозиготності, визначали шляхом співставлення відношень між емпіричними гетерозиготами і емпіричними гомозиготами з аналогічним відношенням, отриманими за теоретичними даними;

коефіцієнт ексцесу (D) кількісно оцінює нехватку або перебільшення фактичної гетерозиготності у досліджуваних популяцій в порівнянні з теоретично розрахованим показниКоM.
Для відбору проб молока використовували лічильник - індикатор ИУ-1. Пробу молока зберігали у пластиковій ємкості (25 мл) та консервували її розчином хромпіку (концентрація 10\%) в кількості 0,2 мл. Проаналізовано біохімічний склад молока від трьох корів кожного генотипу (A1A1, A1A2, А2А2) кожної досліджуваної породи. Вміст жиру та білку в молоці визначали у лабораторії Сумського національного аграрного університету на обладнанні Ultrasonic milk analyzer Master Classic.

Результати досліджень обробляли методами математичної статистики засобами пакету «Statistica-6.1» у середовищі Windows на ПЕОМ.

Результати досліджень. Аналіз розподілу генотипів у корів бурої худоби вказує на те, що більше половини (51\%) становили бажані гомозиготні - A2A2 за бета-казеїном у тварин лебединської породи та майже половину (46\%) у тварин української бурої молочної породи (табл. 1).

Таблиця 1

\begin{tabular}{|c|c|c|c|c|c|c|c|c|c|c|}
\hline \multirow{3}{*}{ Порода } & \multirow{3}{*}{ Розподіл } & \multicolumn{6}{|c|}{ Генотипи } & \multicolumn{2}{|c|}{ Алель, од } & \multirow{3}{*}{$x^{2}$} \\
\hline & & \multicolumn{2}{|c|}{$\mathrm{A} 1 / \mathrm{A} 1$} & \multicolumn{2}{|c|}{$\mathrm{A} 1 / \mathrm{A} 2$} & \multicolumn{2}{|c|}{$\mathrm{A} 2 / \mathrm{A} 2$} & \multirow{2}{*}{$\mathrm{A} 1$} & \multirow[b]{2}{*}{ A2 } & \\
\hline & & $n$ & $\%$ & $\mathrm{n}$ & $\%$ & $\mathrm{n}$ & $\%$ & & & \\
\hline \multirow{2}{*}{ Лебединська } & $\Phi$ & 19 & 13 & 55 & 36 & 77 & 51 & \multirow{2}{*}{0,308} & \multirow{2}{*}{0,692} & \multirow{2}{*}{3,19} \\
\hline & 0 & 14,3 & 9 & 64,4 & 43 & 72,3 & 48 & & & \\
\hline \multirow{2}{*}{$\begin{array}{c}\text { Українська бура } \\
\text { молочна }\end{array}$} & $\Phi$ & 8 & 9 & 41 & 45 & 42 & 46 & \multirow{2}{*}{0,313} & \multirow{2}{*}{0,687} & \multirow{2}{*}{0,203} \\
\hline & 0 & 8,9 & 10 & 39,2 & 43 & 42,9 & 47 & & & \\
\hline
\end{tabular}

Частота алелів та генотипів за локусом гену бета-казеїну у популяції худоби бурих порід

При цьому серед тварин лебединської породи частота гетерозиготних генотипів була нижчою, а гомозигот A1A1 навпаки вищою в порівнянні з українською бурою молочною породою. Використання критерію $X^{2}$ дозволило визначити ступінь відповідності фактичного розподілу генотипів з очікуваним значенням. Розрахунок за формулою ХардіВайнберга показав відсутність суттєвої різниці між фактичними та очікуваними частотами генотипів у тварин української бурої молочної породи. У тварин лебединської породи можна відмітити низьку частоту гетерозиготних генотипів в порівнянні з теоретично розрахованою, хоча ця різниця була статистично незначущою.

Використовуючи генетико-статистичні методи аналізу, шляхом визначення цифрових значень таких генетичних констант як ступінь гомозиготності (Ca), рівень поліморфності (Na) ми намагалися оцінити перспективність роботи з створення стад бурої худоби з генотипом A2A2 за бетаказеїном. Ступінь гомозиготності в досліджуваних популяціях великої рогатої худоби значно не відрізнявся між собою та не мав високого значення. Це може свідчити про недостатній рівень консолідації за даною ознакою. Рівень поліморфності (число ефективно діючих алелів -Na) у локусі бета-казеїну тварин бурих порід майже однаковий у тварин обох популяцій. Тест гетерозиготності (ТГ) у популяції лебединської породи був негативний, що свідчить про недостатню частку гетерозигот в порівнянні з теоретично розрахованою (табл. 2).

\begin{tabular}{|c|c|c|c|c|}
\hline \multirow{2}{*}{ Показники } & \multicolumn{2}{|c|}{ Лебединська } & \multicolumn{2}{|c|}{ Українська бура молочна } \\
\hline & фактичні & теоретичні & фактичні & теоретичні \\
\hline Гетерозиготи & 36 & 64,4 & 41 & 39,2 \\
\hline Гомозиготи & 96 & 86,6 & 50 & 51,8 \\
\hline Коефіцієнт гетеро/гомозиготи & 0,375 & 0,743 & 0,820 & 0,757 \\
\hline Тест гетерозиготності & $-0,170$ & - & 0,065 & - \\
\hline Ступінь гомозиготності, Са, \% & 57,4 & - & 56,9 & - \\
\hline Рівень поліморфності, $\mathrm{Na}$ & 1,74 & - & 1,75 & - \\
\hline Коефіцієнт ексцесу D & $-0,145$ & - & 0,047 & - \\
\hline Частка гомозигот, \% & 63,5 & - & 54,9 & - \\
\hline
\end{tabular}

Генетична структура стад худоби бурих порід за локусом бета-казеїну

Таблиця 2

Коесріцієнт ексцесу (D) підтверджує це твердження. У цілому можна констатувати, що дані генетико-статистичного аналізу свідчать про нестачу гетерозиготних генотипів в популяції лебединської породи. Це підтверджують дані наведені в таблиці 3. 
Значення основних показників мінливості за геном бета-казеїну у стаді худоби лебединської породи

\begin{tabular}{|l|r|r|r|}
\hline \multicolumn{1}{|c|}{ Порода } & $\mathrm{H}_{\circ}$ & $\mathrm{H}_{\mathrm{e}}$ & \\
\hline Лебединська & 0,364 & 0,426 & 0,145 \\
\hline Українська бура молочна & 0,451 & $-0,047$ & 0,430 \\
\hline
\end{tabular}

Основним питанням щодо перспектив використання поліморфізму гену бета-казеїну $€$ його вплив не тільки на

здоров'я людини, а й на якісні показники молочної продуктивності корів (табл. 4).

Якісний склад молока залежно від генотипу за бета-казеїном

Таблиця 4

( $\mathrm{n}=6$ за кожним генотипом)

\begin{tabular}{|c|c|c|c|c|}
\hline \multirow[b]{2}{*}{ Генотип } & \multicolumn{4}{|c|}{ Вміст в молоці,\% } \\
\hline & жиру & білка & лактози & C3M3 \\
\hline \multicolumn{5}{|c|}{ Лебединська } \\
\hline A1A1 & $4,73 \pm 0,209$ & $3,24 \pm 0,065$ & $4,94 \pm 0,063$ & $9,01 \pm 0,114$ \\
\hline $\mathrm{A} 1 \mathrm{~A} 2$ & $4,59 \pm 0,139$ & $3,23 \pm 0,050$ & $4,86 \pm 0,076$ & $8,84 \pm 0,137$ \\
\hline $\mathrm{A} 2 \mathrm{~A} 2$ & $4,68 \pm 0,364$ & $3,31 \pm 0,062$ & $5,06 \pm 0,114$ & $8,97 \pm 0,197$ \\
\hline В середньому & $4,67 \pm 0,139$ & $3,26 \pm 0,033$ & $4,95 \pm 0,051$ & $8,94 \pm 0,085$ \\
\hline \multicolumn{5}{|c|}{ Українська бура молочна порода } \\
\hline A1A1 & $4,65 \pm 0,056$ & $3,22 \pm 0,093$ & $4,99 \pm 0,140$ & $9,08 \pm 0,251$ \\
\hline $\mathrm{A} 1 \mathrm{~A} 2$ & $4,32 \pm 0,173$ & $3,27 \pm 0,031$ & $4,91 \pm 0,053$ & $8,93 \pm 0,095$ \\
\hline $\mathrm{A} 2 \mathrm{~A} 2$ & $4,47 \pm 0,111$ & $3,33 \pm 0,031$ & $5,00 \pm 0,046$ & $9,09 \pm 0,084$ \\
\hline В середньому & $4,45 \pm 0,073$ & $3,28 \pm 0,028$ & $4,94 \pm 0,041$ & $8,98 \pm 0,074$ \\
\hline
\end{tabular}

Середні показники вмісту складових у молоці корів досліджуваних популяцій відповідали стандартам порід. При цьому слід відмітити, що середні показники молочної продуктивності за всіма досліджуваними генотипами також знаходились у межах стандартів. Тварини лебединської породи 3 генотипом A2A2 переважали за вмістом білка та лактози в молоці тварин інших генотипів та середні показники по виборці. За вмістом жиру в молоці перевагу мали тварини з генотипом А1А1. Слід відмітити, що ці різниці були статистично незначущими.

Корови української бурої молочної породи з гомозиготним генотипом A1A1 переважали інших за вмістом жиру, з генотипом A2A2 - мали перевагу за вмістом білка, лактози та сухого знежиреного молочного залишку (СЗМЗ). При цьому різниця показників як між тваринами різних генотипів так і з середніми по виборці були статистично незначущими.

Висновки. Проведене генотипування тварин лебединської та української бурої молочної порід за геном бетаказеїну. Встановлено, що частоти алелів $A 1(0,308-0,313)$ та A2 $(0,687-0,692)$ в локусі гену бета-казеїну у тварин різних

порід відрізнялися. Відповідно частоти генотипів A1A1, A1A2 та А2А2 в залежності від походження різнилися: 9-13\%, 36$45 \%, 46-51 \%$. За даними генетико-статистичного аналізу встановлено надлишок в бета-казеїновому локусі гомозиготних варіантів $A 1 A 1$ та $A 2 A 2$, та нестачу гетерозиготного А1А2 у тварин лебединської породи.

Між тваринами різних генотипів виявлена різниця за якісними характеристиками молока. У тварин різних порід вміст окремих компонентів молока змінювався не однаково залежно від генотипу за бета-казеїном, але ця різниця була статистично незначущою. За вмістом жиру та білка в молоці тварини всіх генотипів відповідали стандарту порід. Таким чином можна констатувати, що формування стад 3 генотипом A2A2 за бета-казеїном не матиме негативного достовірного впливу на продуктивні ознаки корів і таким чином забезпечить збереження високих якісних показників молока худоби стад нового типу. Потребує подальшого вивчення питання впливу генотипу за бета-казеїну як на вміст складових молока так і на його технологічні властивості, з залученням більшої кількості піддослідних тварин.

1. http://www.imilka2.com/

\section{Список використаної літератури:}

2. Givensa I., Aikmana P., Gibsonb T., Browna R. Proportions of $A 1, A 2, B$ and $C \beta$-casein protein variants in retail milk in the UK. Food Chemistry. 2013. Vol. 139, P. 549-552.

3. Fuerer C., Jenni R., Cardinaux L., Andetsion F., Wagnire S., Moulin J., Affolter M. Protein fingerprinting and quantification of $\beta$-casein variants by ultra-performance liquid chromatography-high-resolution mass spectrometry J. Dairy Sci. 2019. Vol. 103, P.1193-1207 https://doi.10.3168/jds.2019-16273.

4. Kaskous S. A1- and A2-Milk and Their Effect on Human Health. Journal of Food Engineering and Technology. 2020. Vol. 9(1), P.15-21.

5. O'Callaghan T. An overview of the A1/A2 milk hypothesis. Dairy Nutrition forum. 2020. Vol. 12, issue 2. P. 1-4.

6. Bentivoglio D., Finco A., Bucci G., Staffolani G. Is There a Promising Market for the A2 Milk? Analysis of Italian Consumer Preferences Sustainability 2020. Vol. 12. P. 2-16. https://doi:10.3390/su12176763

7. Xiaoyang S., Zailing Li, zJiayi Ni, Yelland G. Effects of Conventional Milk Versus Milk Containing Only A2 b-Casein on Digestion in Chinese Children: A RandomizedStudy. JPGN Vol. 69 (3). P. 375-382. https://doi.10.1097/MPG.0000000000002437.

8. Guantario B, Giribaldi M., Devirgiliis C., Finamore A., Colombino E., Capucchio M., Evangelista R, Motta V., Zinno P., Cirrincione S., Antoniazzi S., Cavallarin L., Roselli M. A Comprehensive Evaluation of the Impact of Bovine Milk Containing Different Beta-Casein Profiles on Gut Health of Ageing Mice. Nutrients. 2020, Vol. 12. P. 21-47. doi:10.3390/nu12072147. 
9. Italo Mencarini. A simulation model of dairy herd cjnversion to produce A2 milk. Abstract of a thesis submitted in partial fulfillment of the requirements for the Degree of Master of Agricultural Science. Lincoln University Digital Thesis. 2013. 51 p.

10. Amalfitano N., Cipolat-Gotet C., Cecchinato A., Malacarne M., Summer A., Bittante G. Milk protein fractions strongly affect the patterns of coagulation, curd firming, and syneresis. J. Dairy Sci. 2018. Vol. 102, P.2903-2917. DOI: https://doi.org/10.3168/jds.2018-15524

11. Henrique do Nascimento Rangel A., Cavalcanti Sales D., Antas Urbano S., Geraldo Bezerra Galvãojúnior J., César de Andrade Neto J., de Souza Macêdo C. Lactose intolerance and cow's milk protein allergy. Food Science and Technology. 2016. Vol. 36(2), P. 179-187. http://dx.doi.org/http://dx.doi.org/10.1590/1678-457X.0019.

12. Parashar A., Saini R. A1 milk and its controversy-areview. International Journal of Bioassays. 2015. Vol. 4. №12, P. $4611-4619$

13. Кононова Л.В., Сычова О.В., Омарова Р.С. Необыкновенное коровье молоко. Молочная река. 2016. №3(63), С.62-64.

14. Кузьменко Н.Б., Кузина А.Н. Роль $\beta$-казеина в питании детей первых лет жизни. Лечащий врач. 2016. № 01/16, С.75-80.

15. Gustavsson F., Buitenhuis A., Johansson M., Bertelsen H., Glantz M., Poulsen N. Effects of breed and casein genetic variants on protein profile in milk from Swedish Red, Danish Holstein, and Danish Jersey cows. J. Dairy Sci. 2013. Vol. 97, P.38663877. DOI: http://dx.doi.org/ 10.3168/jds.2013-7312

16. Kostyunina, O. V., 2005. Molekulyarnaya diagnstika geneticheskogo polimorfizma osnovny'kh molochny`kh belkov $i$ ikh svyaz’s tekhnologicheskimi svojstvami moloka. Abstractof Ph. D. dissertation. Dubroviczy.

17. Miluchová, M., Gábor, M., Candrák, J., Trakovická, A., Candráková, K., 2018. Association of Hindlll-polymorphism in kappa-casein gene with milk, fat and protein yield in holstein cattle. Acta Biochimica Polonica. issue 65, № 3, pp. 403-407.

18. Селионова, М. И., Чижова, Л. Н., Суржикова, Е. С., Шарко Г.Н., Михайленко, Т. Н., Чудновец, А. И. Породные особенности аллельного профиля генов, контролирующих молочную продуктивность крупного рогатого скота. Агрозоотехника., 2019. №2 (1). C. 1-12. DOI: https: // 10.15838/alt.2019.2.1.3

19. Ladyka,V., Pavlenko, Y., Sklyarenko, Y. $\beta$-casein gene polymorphism use in terms of brown dairy cattle preservation. Archivos de Zootecniaal. 2021, Vol. 70 (269). P.88-94. DOI: https://doi.org/10.21071/az.v70i269.5422

20. Ладика В.І., Скляренко Ю.І., Павленко Ю.М. Характеристика генетичної структури за геном $\beta$-казеїну плідників, допущених до використання в Україні у 2020 році. Технологія виробництва і переробки продукції тваринництва. 2020, Вип. 1 (156). С. $38-46$.

1. http://www.imilka2.com/

2. Givensa, I., Aikmana, P., Gibsonb, T., Browna, R., 2013. Proportions of A1, A2, B and C $\beta$-casein protein variants in retail milk in the UK. Food Chemistry. issue 139, pp. 549-552.

3. Fuerer, C., Jenni, R., Cardinaux, L., Andetsion, F., Wagnire, S., Moulin, J., Affolter, M., 2019. Protein fingerprinting and quantification of $\beta$-casein variants by ultra-performance liquid chromatography-high-resolution mass spectrometry J. Dairy Sci. issue 103, pp.1193-1207.

4. Kaskous, S., 2020. A1- and A2-Milk and Their Effect on Human Health. Journal of Food Engineering and Technology. issue $9(1)$, pp.15-21.

5. O'Callaghan, T., 2020. An overview of the A1/A2 milk hypothesis. Dairy Nutrition forum. issue 12 (2). pp. 1-4.

6. Bentivoglio, D., Finco, A., Bucci, G., Staffolani, G., 2020. Is There a Promising Market for the A2 Milk? Analysis of Italian Consumer Preferences Sustainability issue 12. pp. 2-16.

7. Xiaoyang, S., Zailing, Li, zJiayi, Ni, Yelland, G., 2019. Effects of Conventional Milk Versus Milk Containing Only A2 bCasein on Digestion in Chinese Children: A Randomized Study. JPGN. issue 69 (3). pp. 375-382.

8. Guantario, B, Giribaldi, M., Devirgiliis, C., Finamore, A., Colombino, E., Capucchio, M., Evangelista, R, Motta, V., Zinno, P., Cirrincione, S., Antoniazzi, S., Cavallarin, L., Roselli, M., 2020. A Comprehensive Evaluation of the Impact of Bovine Milk Containing Different Beta-Casein Profiles on Gut Health of Ageing Mice. Nutrients. issue 12. pp. 21-47.

9. Mencarini, I., 2013. A simulation model of dairy herd cjnversion to produce A2 milk. Abstract of a thesis submitted in partial fulfillment of the requirements for the Degree of Master of Agricultural Science. Lincoln University Digital Thesis. $51 \mathrm{p}$.

10. Amalfitano, N., Cipolat-Gotet, C., Cecchinato, A., Malacarne, M., Summer, A., Bittante, G., 2018. Milk protein fractions strongly affect the patterns of coagulation, curd firming, and syneresis. J. Dairy Sci., issue 102, pp. 2903-2917.

11. Henrique do Nascimento Rangel, A., Cavalcanti Sales, D., Antas Urbano, S., Geraldo Bezerra Galvãojúnior, J., César de Andrade Neto, J., de Souza Macêdo, C., 2016. Lactose intolerance and cow's milk protein allergy. Food Science and Technology, issue. 36(2), pp. 179-187. 4611-4619.

12. Parashar, A., Saini, R., 2015. A1 milk and its controversy-areview. International Journal of Bioassays. issue 4., №12, pp.

13. Kononova, L.V., Sy`chova, O.V., Omarova, R.S., 2016. Neoby`knovennoe korov`e moloko [Extraordinary cow's milk]. Molochnaya reka, issue 3(63), pp. 62-64.

14. Kuz`menko, N.B., Kuzina, A.N., 2016. Rol’ beta-kazeina v pitanii detej pervy`kh let zhizni [The role of beta-casein in the nutrition of children in the first years of life]. Lechashhij vrach, issue 01/16, pp.75-80.

15. Gustavsson, F., Buitenhuis, A., Johansson, M., Bertelsen, H., Glantz, M., Poulsen, N.,. Effects of breed and casein genetic variants on protein profile in milk from Swedish Red, Danish Holstein, and Danish Jersey cows. J. Dairy Sci, issue 97, pp. 3866-3877.

16. Kostyunina, O. V., 2005. Molekulyarnaya diagnstika geneticheskogo polimorfizma osnovny'kh molochny kh belkov $i$ 
ikhsvyaz`s tekhnologicheskimi svojstvami moloka. Abstractof Ph. D. dissertation. Dubroviczy.

17. Miluchová, M., Gábor, M., Candrák, J., Trakovická, A., Candráková, K., 2018. Association of Hindlll-polymorphism in kappa-casein gene with milk, fat and protein yield in holstein cattle. Acta Biochimica Polonica. issue 65, No 3, pp. $403-407$.

18. Selionova, M. I., CHizhova, L. N., Surzhikova, E. S., SHarko G.N., Mihajlenko, T. N., CHudnovec, A. I., 2019. Porodnye osobennosti allel'nogo profilya genov, kontroliruyushchih molochnuyu produktivnost' krupnogo rogatogo skota. [Breed features of the allelic profile of genes that control milk production in cattle]. Agrozootekhnika., issue 2 (1). pp. 1

19. Ladyka,V., Pavlenko, Y., Sklyarenko, Y., 2021. $\beta$-casein gene polymorphism use in terms of brown dairy cattle preservation. Archivos de Zootecniaal. issue 70 (269), pp.88-94.

20. Ladyka V.I., Skliarenko Yu.I., Pavlenko Yu.M. 2020. Kharakterystyka henetychnoi struktury za henom $\beta$-kazeinu plidnykiv, dopushchenykh do vykorystannia v Ukraini u 2020 rotsi [Characteristics of the genetic structure of the $\beta$-casein gene of broods approved for use in Ukraine in 2020]. Tekhnolohiia vyrobnytstva i pererobky produktsii tvarynnytstva., issue 1 (156), pp. 3846.

Ladyka Volodymyr Ivanovych, Doctor of Agricultural Sciences, Professor, Academician of NAAS

Pavlenko Yuliya Mykolayivna, PhD of Agricultural Sciences, Docent, Sumy National Agrarian University

Sklyarenko Yuriy Ivanovych, Doctor of Agricultural Sciences, Senior Researcher, Institute of Agriculture of Northern East of NAAS

Ladyka Lyubov Mikhailivna, PhD of Agricultural Sciences, Docent, Sumy National Agrarian University

Irina Levchenko Volodimirovna, PhD of Agricultural Sciences, Docent, Sumy National Agrarian University

Influence of beta-casein genotype on milk quality indicators in brown cattle

In breeding herds of Lebedinian and Ukrainian brown dairy breeds, studies were conducted to study the polymorphism of the beta-casein gene and its effect on the quality of cow's milk. Genotyping of 242 head of cattle of the above breeds was carried out. Determination of beta-casein gene polymorphism was performed in the genetic laboratory of the Bogomoletz Institute of Physiology. The TagMan@Genotyping system and a set of primers and probes were used for allelic discrimination. It was found that the frequencies of alleles $A 1$ (0.308-0.313) and A2 (0.687-0.692) in the locus of the beta-casein gene in animals of different breeds differed. The population of Lebedinian cows had the highest frequency of the desired A2 allele (0.692), and the Ukrainian brown dairy population had the lowest frequency (0.687). The frequency of the A1 allele was the lowest in cows of Lebedinian breed (0.308) and the highest - in cows of Ukrainian brown dairy breed (0.313). Accordingly, the frequencies of genotypes A1A1, A1A2 and A2A2 differed depending on the origin. The desired genotype was more common in animals of Lebedinian breed (51\%). Heterozygous genotype was more characteristic of animals of the Ukrainian brown dairy breed (45\%). The highest frequency of the A1A1 genotype was characterized by Lebedinian animals (13\%). According to genetic and statistical analysis, an excess of homozygous variants of $A 1 A 1$ and A2A2 in the beta-casein locus was found. Heterozygous A1A2 deficiency was found in animals of Lebedinian breed. There was a difference in the quality of milk between animals of different genotypes. In animals of different breeds, the content of individual components of milk did not vary equally depending on the genotype of beta-casein, but this difference was statistically insignificant. In terms of fat and protein content in milk, animals of all genotypes met the breed standard. Thus, it can be stated that the formation of herds with the A2A2 genotype for beta-casein will not have a negative impact on the productive traits of cows and thus ensure the preservation of high quality of milk of cattle herds of a new type. The small number of experimental animals, in our opinion, was one of the reasons for the lack of a significant difference between the average values of the milk components of cows of different genotypes for beta-casein.

Key words: breed, genotype, casein, selection, genetic markers, fat content, protein content

Дата надходження до редакції 03.12. 2021 р. 